C/NFE 08-01259

OAK RIDGE

ORNL/TM-2010/86

NATIONAL LABORATORY

MANAGED BY UT-BATTELLE

FOR THE DEPARTMENT OF ENERGY

Materials Science and Technology Division

CRADA Final Report

For

CRADA Number NFE 08-01259

Cast CF8C-Plus Stainless Steel for

Turbocharger Applications

P. J. Maziasz, A. Shyam and N. D. Evans

Oak Ridge National Laboratory

K. Pattabiraman, Honeywell Turbo Technologies

Honeywell International

\author{
Prepared by \\ Oak Ridge National Laboratory \\ Oak Ridge, TN 37831 \\ managed by \\ UT-Battelle, LLC \\ for the \\ U.S. Department of Energy \\ under contract DE-AC05-00OR22725
}

Unlimited Release

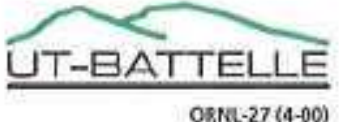




\section{DOCUMENT AVAILABILITY}

Reports produced after January 1, 1996, are generatly avalłable free via the U.S. Department of Energy (OOE) Information Bridge.

Web site httg:/Wwow,ostigowbridge

Reports produced before January 1, 1996, may be purchased by members of the public from the following source.

National Technical Information Service

5285 Port Royal Road

Springfield, VA 22161

Telephore 703-605-6090 (1-800-553-6847)

TDD 703-487-4630

Fax 703-605-6900

E-maif in fo@ntis.fedworld.gov

Wob site http:/hnww.ntis.gow/supportlordernowabout.htm

Reports are available to DOE employees, DOE contractors,

Energy Technology Data Exchange (ETDE) representatives, and International Nutlear Informatton System (INIS)

representatives from the foliowing source.

Office of Sclentific and Technical Information

P.O. Box 62

Oak Ridge, TN 37831

Telephone $865-576.8401$

Fax B65-576-5728

E-mail reportseadonis.osti.gow

Web site http:/hmw.osti.govicontact html

This report was prepared as an account of work sponsored by an egency of the United \$tates Government. Nether the United States Government nor any agency thereof, nor any of their employees, makes any wartanty express or implied, or assumes any legal liability or responsibility for the accuracy, completeness, or usefulness of any infomation, apparatus, prodtsct, or process disclosed, or represents that its use would not infringe privately owned rights. Reference herein to any specific commercial product. process, or service by trade name. trademark, manufacturer, or otherwise, does not necessarily constitute or imply its endorsement, recommendation, or favoring by the Unlted States Government or any agency thereof. the whews and oplntons of authors expressed hereln do not necessarlly state or reflect those of the United States Government or any agency thereof. 
Materials Scienco and Technology Division

CRADA Final Report

For

CRADA Number NFE 08-01258

Cast CF8C-Plus Stalnless Ste日l for Turbocharger Applications

P. J. Maziasz, A. Shyam, and N. D. Evans

Oak Ridge National Laboratory

K. Pattabiraman

Honeywell Turbo Technologies

Honeywell International

\author{
Prepared by \\ Oak Ridge National Laboratory \\ Oak Ridge, TN 37831 \\ managed by \\ UT-Battelle, LLC \\ for the
}

U.S. Department of Energy

under contract DE-AC06-00OR22725

Unlimited Release

Research was supported through a CRADA with Honeywell International, sponsored by the U.S. Department of Energy, Assistant Secretary for Energy Efficiency and Renewable Energy. Technology Commercialization and Development Program, under contract DE-AC05-00OR22725 with Oak Ridge National Laboratory, managed by UTBattelle, LLC. 


\title{
Cast CF8C-Plus Stainless Steel for Turbocharger Applications
}

\author{
CRADA No. NFE 08*01259 \\ between \\ Oak Ridge National Labotatory \\ and \\ Honeywell International
}

\begin{abstract}
The purpose of this Cooperative Research and Development Agreement (CRADA) project is to provide the critical test data needed to qualify CF8C-Plus cast stainless steel for comntercia] production and use for turbocharger housings with upgraded performance and durability relative to standard commercial cast irons or stainless steels. The turbocharger technologies include, but are not limited to, heavy-duty highway diesel engines, and passenger vehicle diesel and gasoline engines. This CRADA provides additional critical high-temperature mechanical properties testing and data analysis needed to qualify the new CF8C-Plus steels for turbocharger housing applications.
\end{abstract}

\section{Background}

New diesel and gasoline engine emissions regulations requice increased fuel economy and reduced emissions, which in tusn are increasing engine and exhaust component temperatures. Diesel engines require turbochargers, and increased temperamies require turbocharger housings with increased temperature capability and durability relative to cast iron. Gasoline engines gain dramatic increases in fuel efficiency and performance fiom turbocharging, and thinner-walled stainless steel turbocharger housings are attractive for lighter-weight, better performance, and lower initial exhaust heat-loss for better catalytic converter performance. CF8C-Plus is a new cast austenitic stainless steel recently developed by Caterpillar and Oak Ridge National Laboratory (ORNL) for improved high-tempexature strength, creep-, fatigue- and agingresistance. CF8C-plus has excellent castability for making complex parts like turbocharger housings. More importantily, it is a low-cost stainless steel witl creep-resistance at $600-900^{\circ} \mathrm{C}$ that is comparable to many solid-solution Ni-based superalloys. A. U.S. Patent was granted in December 2006, and ASTM recognized CF8C-Plus as a new heat resistant alloy grade (HG I0MNN) in November 2008. Stainless Foundry \& Engineering (SF\&E, Milwaukee, WI) obtained the first commercial license for CF8C-Plus steel in May 2008. Caterpillar commercialized CF8C-Plus cast stainless steel for its Caterpillar regeneration systern (CRS) burner for cerantic diesel particulate filters (DPF) late in 2006, and to date has produced over 500 tons of CF8C-Plus for this single application on heavy-duty truck diesel engines (Fig. 1). Diesel fiel is injected into the exlaaust from the turbocharger to begin the combustion process that removes particles clogging the DPF. The CRS unit is subject to very high temperatures of $900^{\circ} \mathrm{C}$ or above, and rapid thermal cycling. Many CRS units have been in service almost 4 years, and to date, there have been no fajlures. The purpose of this CRADA was to do the additional critical high-temperature mechanical properties testing needed to qualify the new CF8C-Plus steels for turbocharger housing applications. 


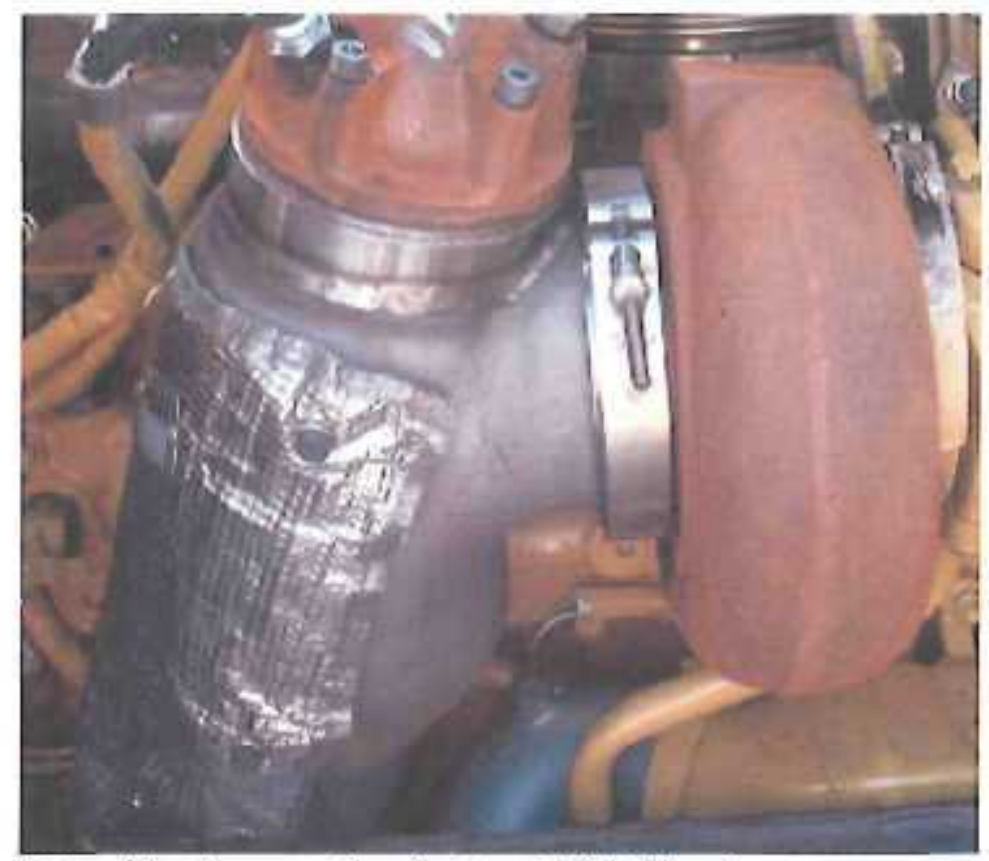

Caterpillar Regeneration System (CRS) Housing

A

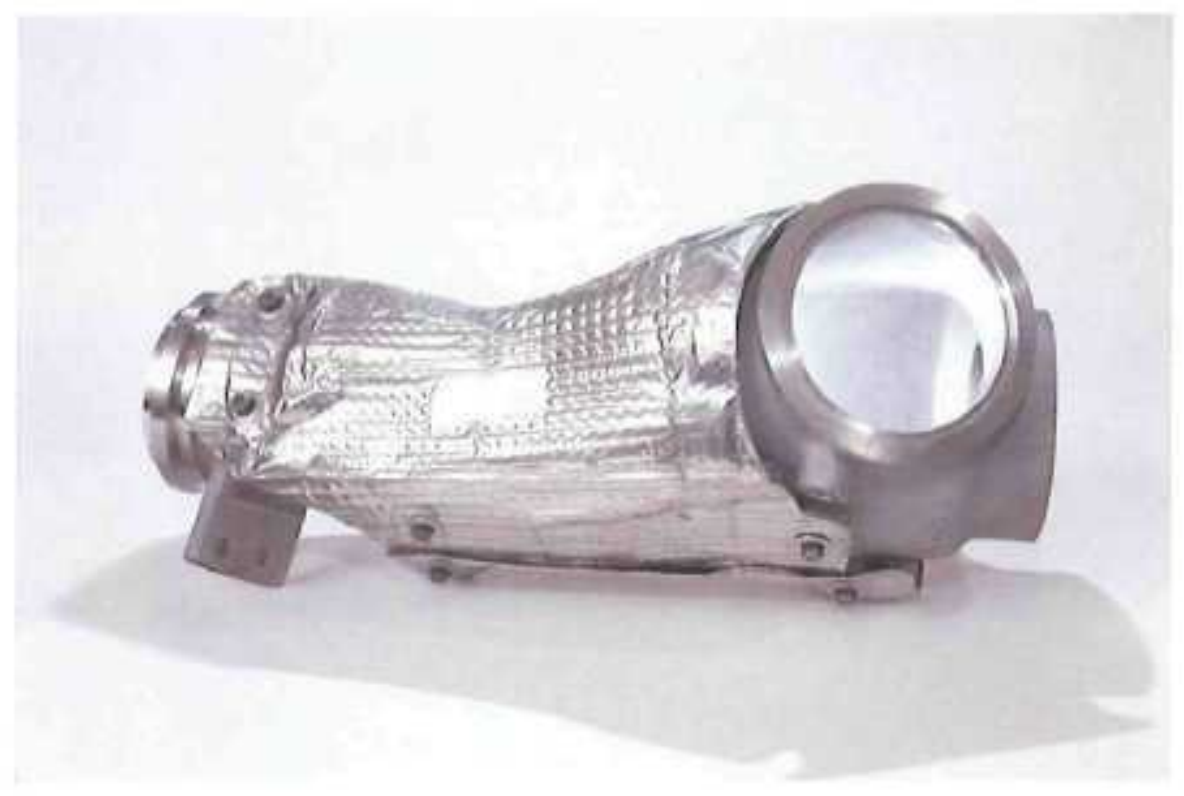

B

Fig. 1 - Pictures of a) a CF8C-Plus cast austenitic stainless steel CRS unit adjacent to the turbocharger on a diesel engine, and b) a fresh CRS unit by itself, showing the heat-shield needed to protect other engine-components. Diesel fuel is injected into the exhaust from the turbocharger to begin the combustion process that removes particles clogging the DPF. The CRS unit is subject to very high temperatures and rapid thermal cycling. 


\section{Objectives}

The objective of this CRADA project was to obtain a typical commercial heat of static-cast CF8C-Plus steel, so that all important physical and mechanical properties needed to qualify a steel or stainless steel for the turbocharger application could be measured on that one beat. Another objective of this CRADA was to then compare this appropriate data base directly with other stainless steels or alloys that are being used or considered for turbocharger housing applications, particularly for heavy-duty on-highway diesel engines. If CF8C-Plns steel shows acceptable high-temperature behavior, then the final objective of this CRADA was to cast prototype turbocharger housing components.

\section{Benefits to DOE Mission}

This CRADA project directly benefited the DOE/EERE Technology Commercialization and Development Program because it took a patented and commercially-availabte technology developed on the DOE/EERE Office of Vehicle Teclunologies program, and provided another related opportunity to dramatically expand the commercial impact in 1-2 years. CF8C-Plus cast staitless steel will enable turbochatgers to withstand higher diesel engine temperatures, and thus directly enable both better fuel efficiency and lower emissions. These new steels also overcome the barter of reduced lifetime at higher operating temperatures, because normally increased temperature and increased lifetime are trade-offs. Scientific and rapid alloy design provided the CF8C-Plus steel with improved temperature capability, as weil as improved durability and reliability. Development of CF8C-Plus steel was recognized witl a 2003 R\&D100 Award, and commercialization was recognized with an Award for Excellent in Technology Transfer in 2009 by the Federal Laboratory Consortium. Honeywell commercialization of CF8C-Plus stainless steel for turbocharger housing applications will expand application to world-wide turbocharger applications for truck and passenger diesel engine applications, and would injpact torbocharging for clearer and more efficient passenger gasoline engines as well.

\section{Technical Discussion of Work Performed}

The original wotk-scope for this 18-month CRADA had six main tasks. Task 1 was for Honeywell to obtain a commercial heat of keel bars of as-cast CF8C-Plus steel for producing tensile, creep and fatigue specimens. Task 2 was for ORNL to do short-term creep-testing of CF8C-Plus at $600-900^{\circ} \mathrm{C}$; Task 3 was for ORNL to similarly do isothemal low-cycle fatigne (LCF) testing of CF8C-Plus steel between $600-900^{\circ} \mathrm{C}$. Task 4 was for Honeywell to evaluate CF8C-Plus for the turbocharger housing application, including fabrication of prototype components and engine-tests̀ng. Task 5 was for ORNL to do selected longer-term creepurupture testing on a sub-set of CF8C-Plus steel specimens that did not fail in Task 2. Task 6 was for Honeywell to consider all the test data on cast CF8C-Plus stainless steel, and make a go/nongo decision on further commercialization for the nurbocharger housing application.

For diesel engine turbocharger applications, HK-30Nb cast stainless steel is commercially available and can meet many of the Honeywell diesel engine turbocharger housing requirements. HK30-Nb steel is more expensive than CF8C-Plus steel, and can be more difficult to cast. Therefore, an additional task of this CRADA project related to Task 6 became direct compatison of CF8C.Plus and HK-30Nb steels at $600-900^{\circ} \mathrm{C}$. 
The composition of the heat of CF8C-Plus cast steel (N276/N277) obtained by Honeywell from Stainless Foundry \& Engineering is given in Table 1, and the composition of the heat of HK$30 \mathrm{Nb}$ provided by Honeywell is also included. Pictures of the keel bars or test blocks used to machine mechanical properties specimens are shown in Fig. 2.

\begin{tabular}{llllllllllllll}
\multicolumn{10}{c|}{ Table 1-Alloy Composition (wt.\%, balance Fe) } & & & \\
Alloy & $\mathrm{Cr}$ & $\mathrm{Ni}$ & $\mathrm{Mn}$ & $\mathrm{Nb}$ & $\mathrm{Mo}$ & $\mathrm{Cu}$ & $\mathrm{Si}$ & $\mathrm{C}$ & $\mathrm{N}$ & $\mathrm{P}$ & $\mathrm{S}$ \\
CF8C-Plus & 19.1 & 12.5 & 3.5 & 0.94 & 0.35 & 0.26 & 0.59 & 0.09 & 0.24 & 0.024 & 0.005 \\
N276 & & & & & & & & & & & \\
CF8C-Plus & 19.3 & 12.5 & 3.5 & 0.94 & 0.34 & 0.26 & 0.58 & 0.09 & 0.27 & 0.024 & 0.004 \\
N277 & & & & & & & & & & & \\
HK30-Nb & 25.2 & 19.4 & 1.2 & 1.16 & 0.27 & 0.05 & 1.55 & 0.29 & - & 0.016 & 0.001
\end{tabular}

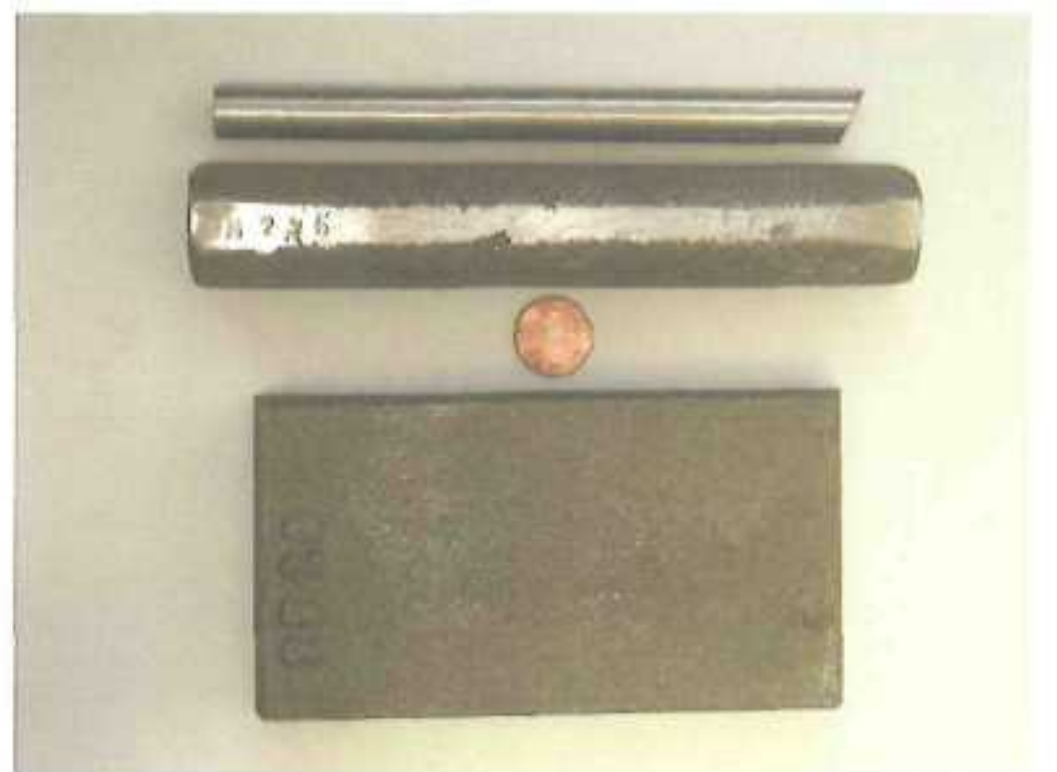

Fig. 2 - Keel bar of as-cast CF8C-Plus (heat N276), top, and cast block of HK-30Nb, bottom, with U.S. penny shown for size reference inbetween. The rod shown above the keel bar is the maximum diagonal length extracted (electro-discharge machining, or EDM) from the HK-30Nb keel bars for producing LCF specimens.

\section{Physical Properties Comparison of CF8C-Plus and HK-30Nb Austenitic Stainless Steels}

Thermal conductivity and thermal expansion are important properties for designers, and these properties help determine complex stresses that can occur in components subjected to different temperatures and thermal gradients, or thermal cycling. The physical properties for the N277 heat of CF8C-Plus steel and for the HK-30Nb steel were provided by Honeywell, whereas the data on heat 1 of CF8C-Plus come from previous work by Caterpillar. The thermal expansion 
data is given in Fig. 3, and the thermal conductivity data is given in Fig. 4. The thermal expansion data for the two different heats of CF8C-Plus are very similar, and both show less expansion than the $\mathrm{HK}-30 \mathrm{Nb}$ steel, and in most engineering applications, lower expansion is better. The thermal conductivities of the two different heats of CF8C-Plus steel are also very similar. The HK-30Nb steel shows similar thermal conductivity up to approximately $500^{\circ} \mathrm{C}$, but then shows measurably lower conductivity at higher temperatures. The combination of better thermal conductivity and lower thermal expansion would give lower thermal stresses for a given temperature difference or gradient for CF8C-Plus steel compared to $\mathrm{HK}-30 \mathrm{Nb}$, which should be beneficial for constrained component applications.

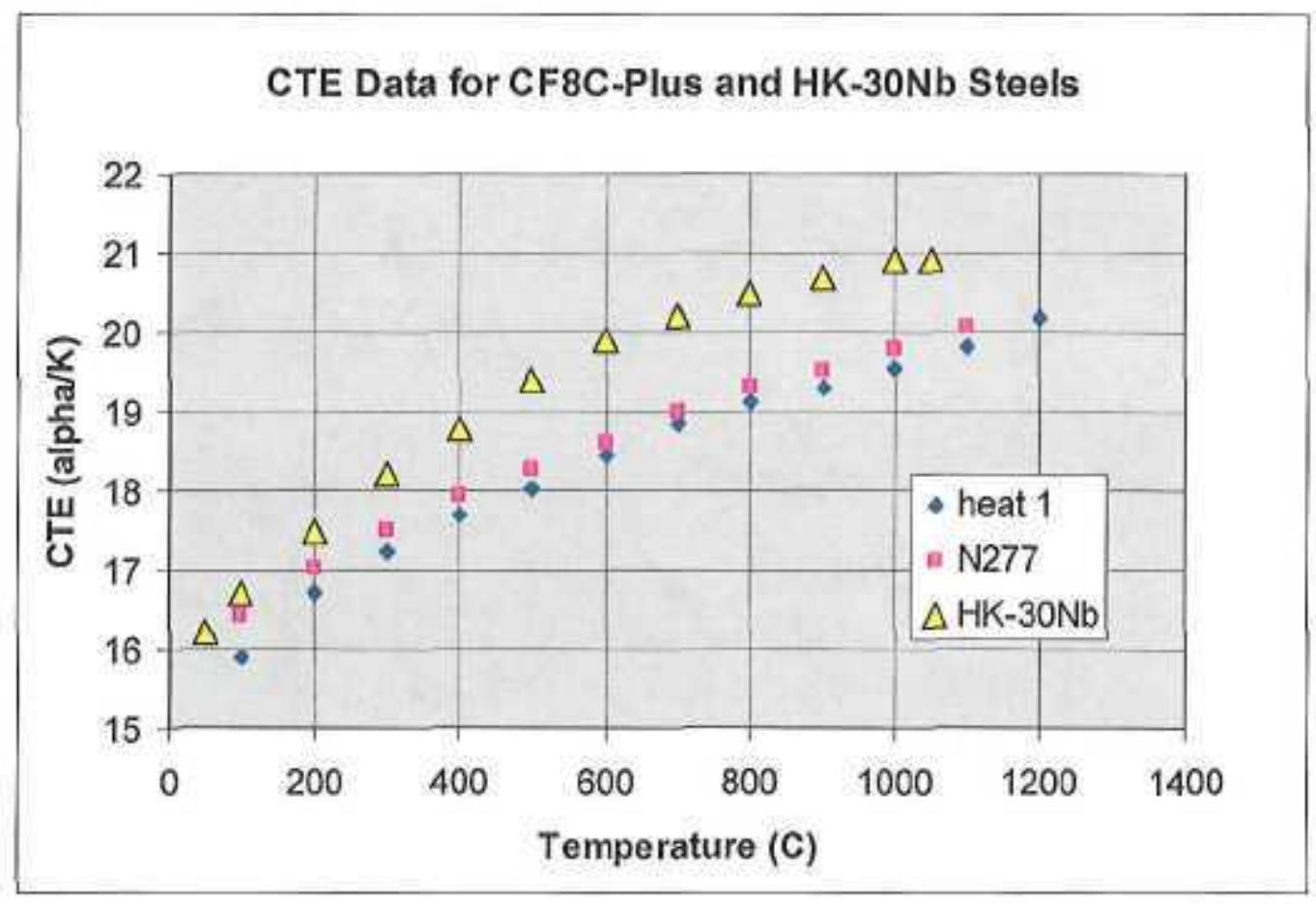

Fig. 3 - Measurement of coefficient of thermal expansion (CTE) for CF8C-Plus and HK-30Nb cast austenitic stainless steels. Data for the N277 heat of CF8C-Plus steel and the HK-30Nb steel were provided by Honeywell for this CRADA project. Data for heat 1 of CF8C-Plus steel was provided to ORNL previously by Caterpillar. 


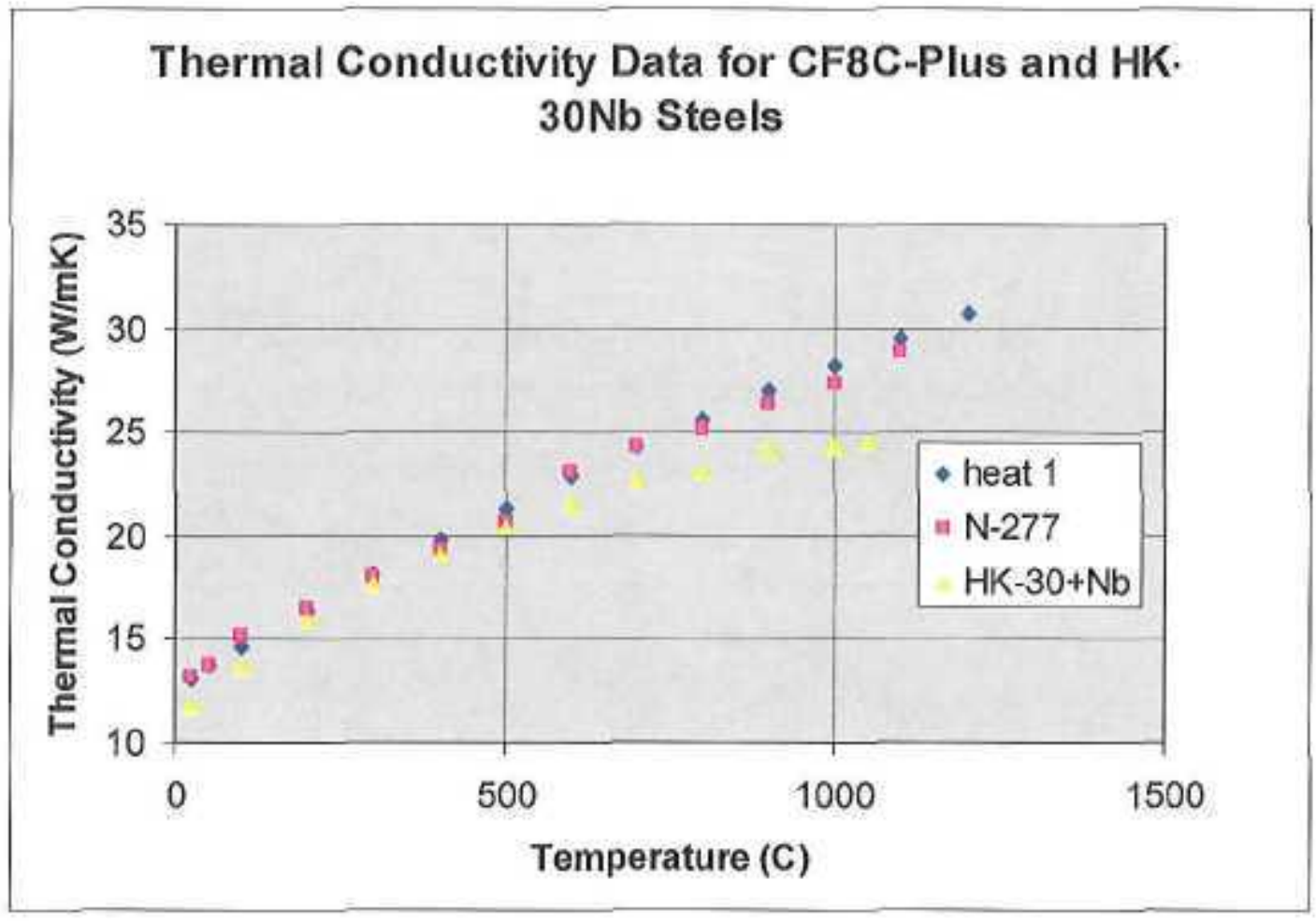

Fig. 4 - Measurements of thermal conductivity CF8C-Plus and HK-30Nb cast austenitic stainless steels. Data for the N277 heat of CF8C-Plus steel and the HK-30Nb steel were provided by Honeywell for this CRADA project. Data for heat 1 of CF8C-Plus steel was provided to ORNL previously by Caterpillar.

\section{Microstructure of As-Cast CF8C-Plus and HK-30Nb Steels}

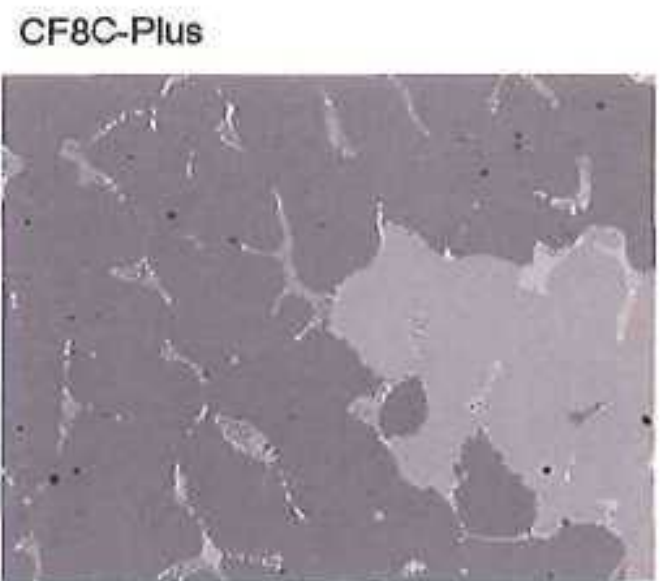

$$
\text { HK30Nb }
$$

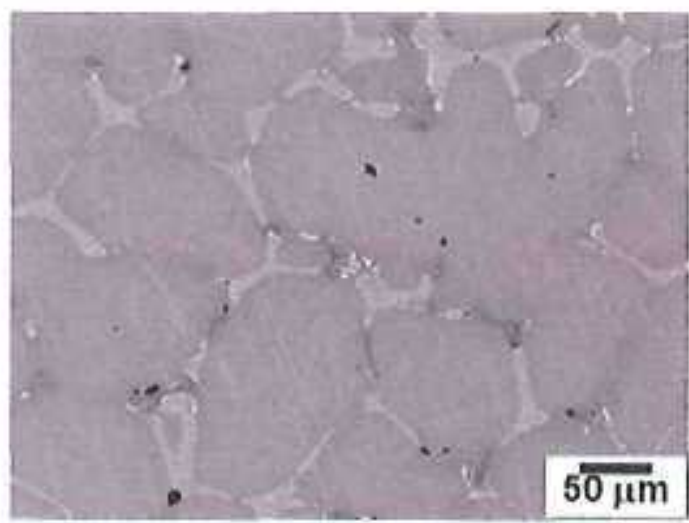

BS SEM

Fig. 5 - Back-scattered scanning electron microscope (BS SEM) images of the microstructures of as-cast CF8C-Plus and $\mathrm{HK}-30 \mathrm{Nb}$ stainless steels. Both have equiaxed dendritic grain structures, with colonies of interdendritic precipitation, which are mainly $\mathrm{NbC}$ in the CF8C-Plus steel, and mixtures of $\mathrm{NbC}$ and $\mathrm{Cr}$-rich $\mathrm{M}_{23} \mathrm{C}_{6}$ in the $\mathrm{HK}-30 \mathrm{Nb}$ steel. 


\section{High-Temperature Mechanical Properties Evaluation of CF8C-Plus Steel}

\section{A) High-Temperature Tensile Properties}

The tensile properties of CF8C-Plus at $600-800^{\circ} \mathrm{C}$ were provided by Honeywell, whereas the tensile properties of $\mathrm{HK}-30 \mathrm{Nb}$ were measured at $600-900^{\circ} \mathrm{C}$ at ORNL. As-cast CF8C-Plus steel has yield-strength (YS) of 132-142 MPa and ultimate tensile strength (UTS) of 300-382 MPa in this temperature range, with total elongation of $17.6-23 \%$. As-cast HK-30Nb has YS of $96-163$ $\mathrm{MPa}$ and UTS of $217-283 \mathrm{MPa}$ in this same temperature range, and total elongation of $22-36 \%$. Comparison of YS at $600-800^{\circ} \mathrm{C}$ for as-cast CF8C-Plus and HK-30Nb steels is shown in Fig. 6. Whereas $\mathrm{HK}-30 \mathrm{Nb}$ is slightly stronger at $600^{\circ} \mathrm{C}$, and both stainless steels have similar YS values at $700^{\circ} \mathrm{C}, \mathrm{CF} 8 \mathrm{C}$-Plus steel has a definite YS advantage at $800^{\circ} \mathrm{C}$.

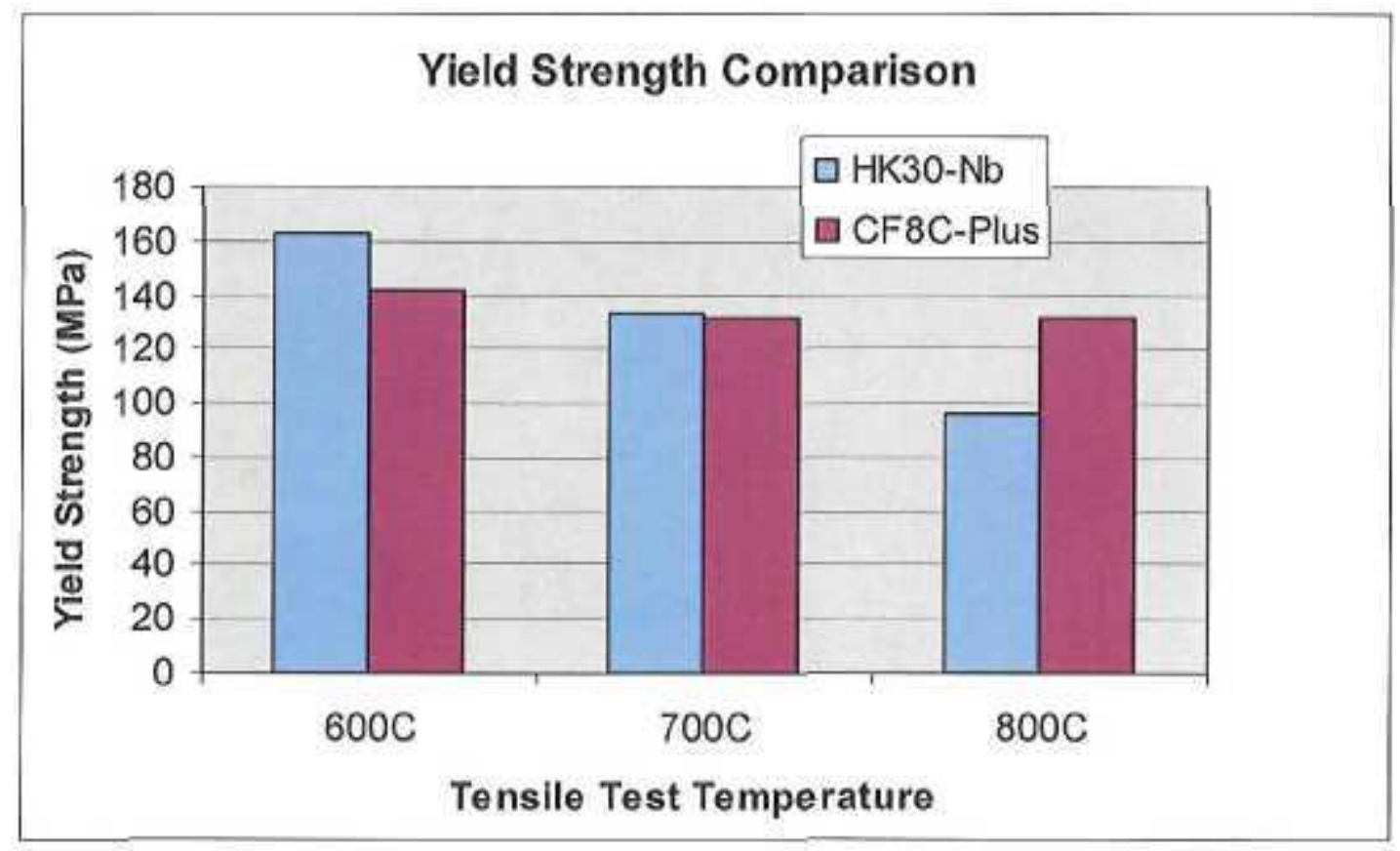

Fig. 6 - Comparison of YS of as-cast CF8C-Plus and HK-30Nb austenitic stainless steels tensile tested at 600,700 and $800^{\circ} \mathrm{C}$ in air.

\section{B) High-Temperature Creep and Creep-Rupture Properties}

Creep/tensile specimens were machined from the as-cast keel bars of CF8C-Plus steel (heats N276 and N277), and 24 creep-rupture tests were run in air at a variety of stresses at 600,700 , 800 , and $900^{\circ} \mathrm{C}$. . Many of these new data include rupture lives that are under $500 \mathrm{~h}$, but there are a number of longer-term data in the 2000-3,000 h range as well, and these creep data are consistent with prior creep-rupture data generated on cast CF8C-Plus steel. 
Several creep-rupture tests were also run at ORNL on the HK30-Nb steel at the same test conditions used for the N276/277 heats of CF8C-Plus steel, and rupture lives for both steels are compared in Fig. 7. Generally, the creep-rupture life of CF8C-Plus steel is about 10 times greater than that of the $\mathrm{HK} 30-\mathrm{Nb}$ steel for this limited comparison, and this is due to the secondary creep-rate of the CF8C-Plus steel being at least 10 times lower as well.

\section{B) High-Temperature Low Cycle Fatigue (LCF) Properties}

Button-head and smooth-shoulder LCF specimens were machined from the as-cast keel bars of CF8C-Plus steel, and isothermal fatigue tests were run in air for a range of total strain values at temperatures of $600,700,800$ and $900^{\circ} \mathrm{C}$. All tests were run in the strain-controlled mode, with a triangular waveform and strain rate of $0.05 \%$ per second. A total of $54 \mathrm{LCF}$ tests were run on CF8C-Plus steel, with most of those at an $R$ value of -1 , but some of them at an $R$ value of 0.1 , where R-value is the ratio of minimum to maximum strain for the cycle. For total strains of about $2 \%$ or less, all tests showed good fatigue resistance, with most approaching an endurance limit at about $0.2 \%$ strain at most temperatures. Fatigue resistance was slightly better at $600^{\circ} \mathrm{C}$, and similar at $700-900^{\circ} \mathrm{C}$. For the same temperature, LCF tests for $\mathrm{R}=0.1$ were generally similar to those run at $\mathrm{R}=-1$.

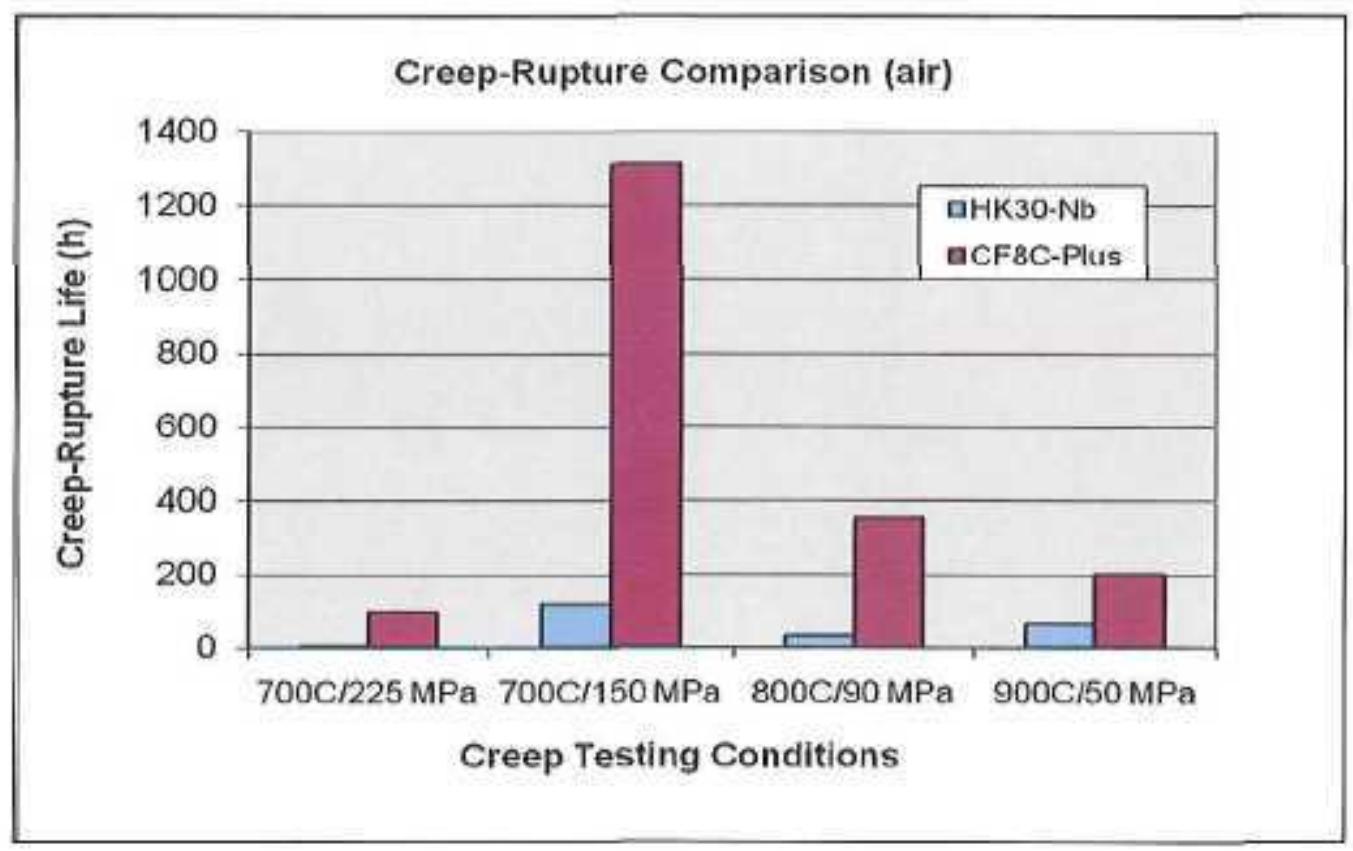

Fig. 7 - Comparison of creep-rupture lives of as-cast CF8C-Plus and HK-30Nb steels for several different creep temperature and stress conditions. CF8C-Plus steel has more creepresistance then $\mathrm{HK}-30 \mathrm{Nb}$ at each of these creep-rupture conditions. 


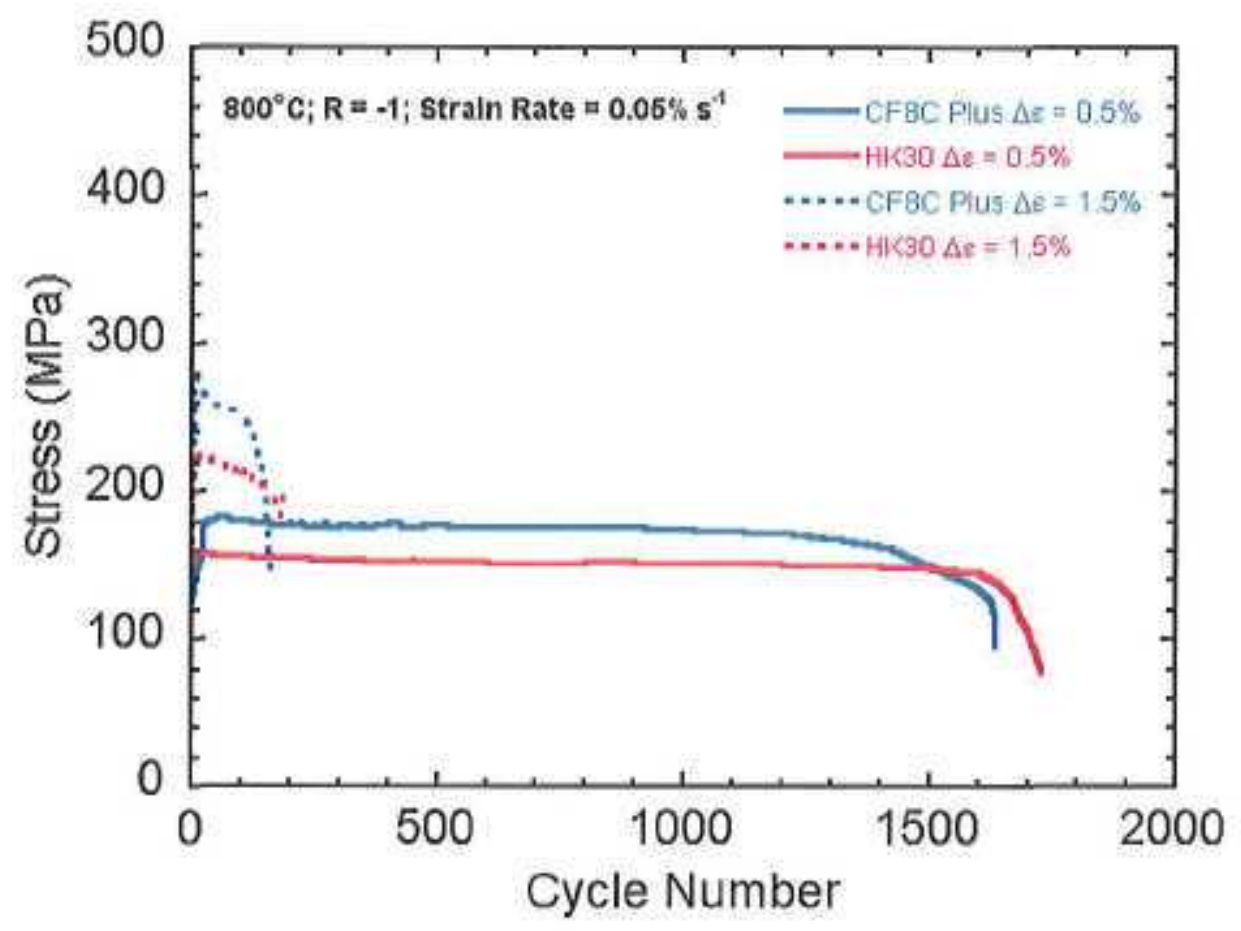

Fig. 8 - Peak stress per cycle plotted as a function of cycles for isothermal LCF testing of ascast CF8C-Plus and HK-30Nb stainless steels at $800^{\circ} \mathrm{C}$, in air at $\mathrm{ORNL}$, with $\mathrm{R}=-1$.

A few isothermal LCF tests were also run on as-cast HK30-Nb stainless steel, for comparison with CF8C-Plus steel, at 600 and $800^{\circ} \mathrm{C}$. Both CF8C-Plus and HK-30Nb have generally similar LCF behavior in terms of cycles to failure for these test conditions. There are however, some subtle differences between the two stainless steels that can be observed after more detailed analysis of the LCF behavior. Fig. 8 shows plots of the maximum stress for each strain-cycle (tests run in strain-controlled mode) for as-cast CF8C-Plus and HK-30Nb steels at two different total strain values, at $800^{\circ} \mathrm{C}$ and $\mathrm{R}$ of -1 . At the higher total strain value of $1.5 \%$, both CF $8 \mathrm{C}$ Plus and $\mathrm{HK} 30-\mathrm{Nb}$ harden rapidly before softening and failure, and the CF8C-Plus steels shows significantly more strain-hardening at this condition than $\mathrm{HK}-30 \mathrm{Nb}$ steel. At the lower total strain level of $0.5 \%$ strain, again CF8C-Plus steel strain-hardens and maintains higher stress levels than HK-30Nb until failure. The total lives to failure were similar for both steels under all conditions tested.

\section{Turbocharger Component Trials With CF8C-Plus Steel}

Honeywell began turbocharger housing prototyping activities by investment casting the endcover for a the turbocharger housing for a C-15 Caterpillar diesel engine, as shown in Figure 11. This prototyping was done by Stainless Foundry \& Engineering. Additional component prototyping and testing of CF8C-Plus steel for turbochargers will be part of a follow-on CRADA project with Honeywell. 


\section{Inventions}

None

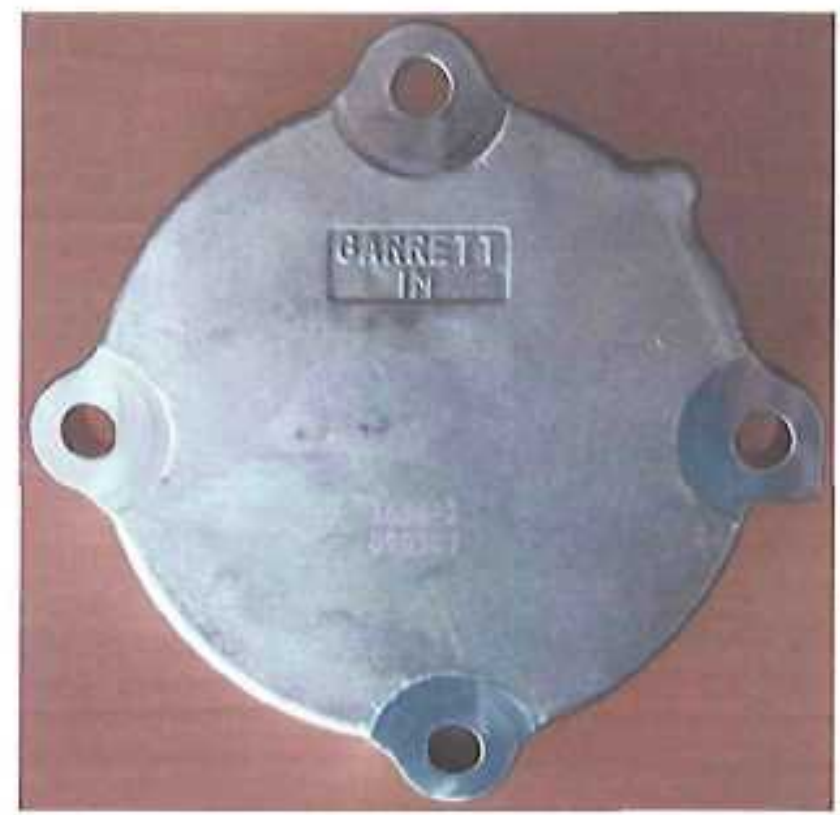

A

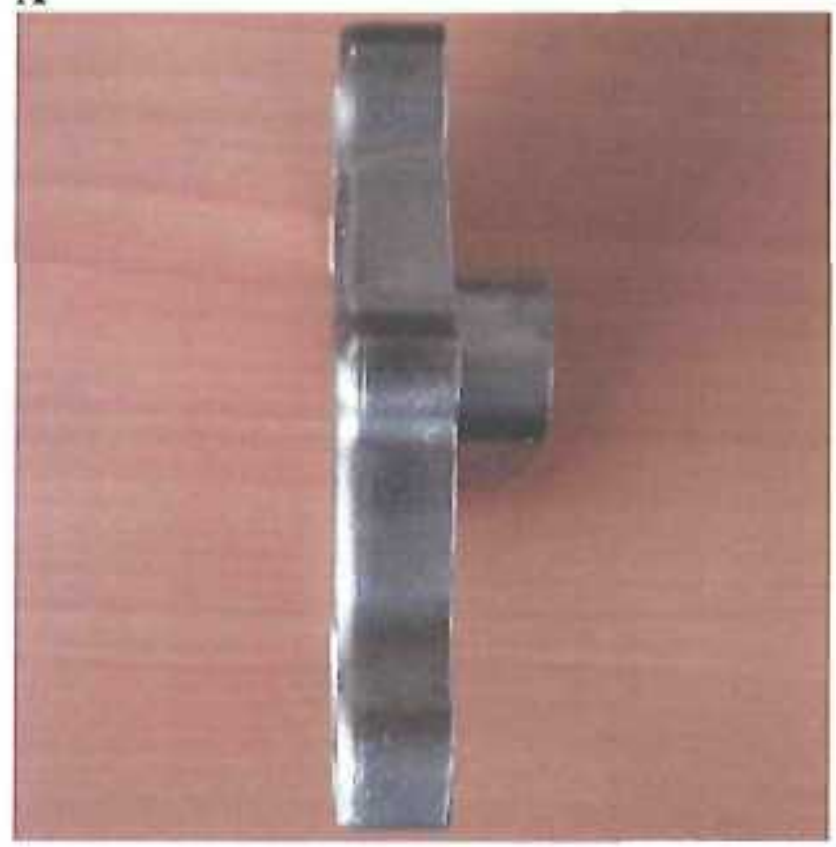

B

Fig. 9 - Investment cast end-cover of CF8C-Plus stainless steel for the turbocharger housing of a C-15 on-highway diesel engine, for A) outside face view, and B) side-view. 


\section{Plans for Fufure Collahoration}

In August 2009, ORNL signed another CRADA with Honeywell (NFE-08-01671) entitled "Materials for Advanced Turbocharger Design and Applications," funded by the DOE/EERE Office of Vehicle Technologies Propulsion Materials Program. This new CRADA has a much broader scope, encompassing both the turbine and compressor portions of the turbocharger, addressing rotors, shatts and housings, for a 36 month period. Progress made on qualifying and testing CF8C-Plus for prototype turbine housings in this CRADA project will continue in the next CRADA project, but the new CRADA will consider both diesel and passenger gasoline engine turbocharger applications.

\section{Conclustons}

A new heat of as-cast CF8C-Plus stainless steel was thoroughly tested for creep-zupture and LCF behavior at $600-900^{\circ} \mathrm{C}$, and shown to have good creep and $\mathrm{LCF}$ resistance for the diesel engine turbocharger application. CF8C-Plus also showed good castability for limited trials for investment-cast turbocharger housing parts. CF8C-Plus steel has better ereep-lupture resistance than HK-30Nb steel for limited tesling at 700-900 ${ }^{\circ} \mathrm{C}$. Cast CF8C-Plus and HK-30Nb steels have similarly good LCF properties for limited testing and comparison at 600 and $800^{\circ} \mathrm{C}$. The high-temperature physical and mechanical properties measured for as-cast CF8C-Plus stainless steel to date support futther consideration for prototype testing of existing turbocharger housing designs, or modified housing designs to take advantage of the creep-resistance and castability.

\section{Acknowledgements}

We would like to thank D. Ray Johnson, DOE/EERE/OVT Ptoptlsion Materials Program Manager, for help in setting of this first ORNL CRADA with Honeywell, and helping secure the special funding from DOE.

We would like to thank Joln Shingledecker of the Mechanical Properties and Mechanics Group at ORNL (now with the Electric Power Research Institute (EPRI)) for generating much of the creep-rupture data on as-cast CF8C-Plus steel, and for expert creep data analysis. Thanks to Jeremy Moser for finishing the creep-lupture testing on CF8C-Plks and HK-30Nb steels, and to Christopher Stevens for high temperature tensile testing.

Thanks to Antoine Claude of Honeywell Turbo Technologies in France for detailed technical project management and coordination with the mechanical properties testing at $\mathrm{ORNL}$. 


\section{DISTRIBUTION}

Internal Distribution

C. A. Blue, 4500 S, MS- 6134

Angie Brock, ORNL Office of Technology Transfer, $4500 \mathrm{~N}, \mathrm{MS}-6196$

P. A. Carpenter, DOE-ORNL Site Office, 4500N, MS-6269

N. D. Evars, $4500 \mathrm{~S}$, MS-6115

E. P. George, 4500S, MS-6115

R. L. Hamilton, DOE Partnerships Office, 4500N, MS-6196

D. R. Hamuin, OTIC, 5300, MS-6254

D. Ray Johnson, 4515, MS-6066

E. Lasa-Curzio, 4515, MS-6069

P. J. Maziasz, 4500S, MS-61 15

Mary Rawlins, DOE-ORNL Site Office, 4500N, MS-6169

M. Reeves, 4500N, MS-6196

T. M. Rosseel, 4500S, MS-6161

A. Shyam, 4515 , MS- 6069

P. F. Tortorelli, 4500S, MS-6134

S. J. Zjnkle, 4500S, MS-6132

DOE-WFO, 1000, MS-6269

External Distribution

Antoine Claude. Honeywell Turbo Technologies, France

Wendolyn S. Holland, Department of Energy, EE-13, 1000 Independence Ave., S. W. FORS

Building. Washington, DC 20585

W. C. Knowles, Director, Engineering Transformation \& Validation, Honeywell Tarbo

Technologies, $3201 \mathrm{~W}$. Lomita Blvd., Torrance, CA 90505

G. D. LaRue, Fellow, Core Technologies, Mechanical Structures and Fatigue Group, Honeywell

Turbo Technologies, 3201 W. Lomita Blvd., Torrance, CA 90505

E. Liang, Structures $\&$ Fatigue Global Manager, Core Technologies, Honeywell Turbo Technologies, 3201 W. Lomita Blvd., Tonrance, CA 90505

Pat Pattabiraman, Global Materials Engineering Manager, Honeywell Turbo Technologies, 3201

W. Lomita Blyd., Torrance, CA 90505 